\title{
EARLY WARNING OF INSTABILITY DURING MESOPHILIC ANAEROBIC DIGESTION OF CHICKEN MANURE
}

\author{
CHEN, L. ${ }^{1,3}-$ ZhENG, T. ${ }^{1,2^{*}}-$ CAO, Q. ${ }^{3}-$ ZHOU, Y. ${ }^{4}-$ LIU, X. ${ }^{3}-$ LI, D. ${ }^{3 *}$ \\ ${ }^{1}$ Institute of Urban and Rural Mining, Changzhou University, Changzhou 213164, China \\ ${ }^{2}$ Guangzhou Institute of Energy Conversion, Chinese Academy of Sciences, Guangzhou 510640, \\ China
}

${ }^{3}$ Key Laboratory of Environmental and Applied Microbiology, Environmental Microbiology Key Laboratory of Sichuan Province, Chengdu Institute of Biology, Chinese Academy of Sciences, Chengdu 610041, China

${ }^{4}$ Chengdu Zhongke Energy \& Environmental Protection Co. Ltd, Chengdu 610041, China

\author{
*Corresponding author \\ e-mail: zhengtao@ms.giec.ac.cn
}

(Received 29 ${ }^{\text {th }}$ Aug 2019; accepted $14^{\text {th }}$ Nov 2019)

\begin{abstract}
Anaerobic digestion (AD) of chicken manure (CM) is easily inhibited by excessive ammonia. To determine early warning indicators of this process, mesophilic $\mathrm{AD}$ of $\mathrm{CM}$ was conducted by organic loading rate $(\mathrm{OLR})$ from 1.0 to $7.0 \mathrm{~g}$ volatile solids $(\mathrm{VS}) /(\mathrm{L} \cdot \mathrm{d})$. Process parameters were monitored every day. At the maximum stable OLR of $5.0 \mathrm{~g} \mathrm{VS} /(\mathrm{L} \cdot \mathrm{d})$, the volumetric methane production rate reached the maximum value of $1.13 \mathrm{~L} /(\mathrm{L} \cdot \mathrm{d})$, and the yield of methane was $178 \mathrm{ml} / \mathrm{g}$ VS. Meanwhile, the total and free ammonia nitrogen increases to 3900 and $300 \mathrm{mg} / \mathrm{L}$ (the maximum value), respectively. Bicarbonate alkalinity (BA) and volatile fatty acid (VFA) values were $12200 \sim 17400 \mathrm{mg} / \mathrm{L}$ and $1000 \sim 2200 \mathrm{mg} / \mathrm{L}$, respectively. This process was severely inhibited by high ammonia concentration when the OLR reached 6-7 g VS/(L·d). According to our study, the most useful early warning indicators are $\mathrm{CH}_{4} / \mathrm{CO}_{2}, \mathrm{VFA} / \mathrm{BA}$, and individual VFAs for AD of CM.
\end{abstract}

Keywords: chicken manure, anaerobic digestion, organic loading rate, early warning indicators, ammonia inhibition

Abbreviations: AD: anaerobic digestion; CM: chicken manure; OLR: organic loading rate; VFA: volatile fatty acid; BA: bicarbonate alkalinity; TAN: total ammonia nitrogen; FA: free ammonia; CSTR: continuous stirred tank reactor; TS: total solid; VS: volatile solid; HRT: hydraulic retention time; FID: flame ionization detector; PA: partial alkalinity; IA: intermediate alkalinity; TA: total alkalinity; VMPR: volumetric methane production rate; MY: methane yield; ORP: redox potential

\section{Introduction}

Anaerobic digestion (AD) is an effective approach to minimizing organic waste and recovering valuable energy (Cioabla et al., 2013). AD is a multi-stage biochemical process (MBP) in which complex organic materials undergo the reaction series of hydrolysis, acidogenesis, acetogenesis, and methanogenesis. Each metabolic stage is controlled by various types of microorganisms, which differ in their habitat requirements, nutritional needs, ability, and growth kinetics to tolerate environment stresses.

Chicken manure (CM) has higher nitrogen contents than other substrates, such as cow manure, pig manure, waste active sludge, and food waste (Qiao et al., 2011). This nitrogen is translated to amino acids, which can be used to synthetize substrate for cell utilization. However, excess nitrogen is further decomposed to ammonia, which exerts a 
toxic inhibitory effect on microorganism metabolism, and causes failure of AD under high organic loading rates (OLR) (Angeladaki et al., 2003; Malollari et al., 2016). Several previous studies have reported AD inhibition at 1.5 to $4.0 \mathrm{~g} \mathrm{~N} / \mathrm{L}$ of ammonia concentrations for different strains and culture conditions (Hashimoto, 1986; Hendriksen et al., 1991), and severe inhibition at higher ammonia concentrations. Ahring (1995) reported that AD of livestock was inhibited when ammonia nitrogen (AN) concentrations were 3000 4000 mg/L. Hashimoto (1986) and Zeeman (1985) reported that $\mathrm{AD}$ process was imbalanced at $2500 \mathrm{mg} / \mathrm{L}$ and $1700 \mathrm{mg} / \mathrm{L}$ of total ammonia nitrogen (TAN), respectively. Furthermore, methanogens are severely inhibited, and more than $80 \%$ of methane production is suppressed, at TAN values of $8000 \mathrm{mg} / \mathrm{L}$ (Krylova et al., 1997).

However, the non-ionized form of ammonia nitrogen: free ammonia (FA), also influences AD inhibition. Studies have shown that it is FA rather than TAN that inhibits methanogenesis. For example, AD inhibition in livestock waste and swine manure occurred at FA concentrations of 700 1100 mg/L (Kayhanian, 1994).

Hence, to maintain steady operation, most large-scale AD are usually operated at low OLR, resulting in a less efficient, low biogas production, and less economic process (Tampio et al., 2014). Ensuring stable AD under high OLR is an urgent problem that should be solved. Previous research has involved monitoring and controlling the process to improve stability and efficiency ( $\mathrm{Li}$ et al., 2014), using a number of parameters including $\mathrm{pH}$, alkalinity, volatile fatty acids (VFAs), AN, methane contents, biogas production, coupling indicators, and alkalinity ratios. However, the early warning indicators of AD inhibition differed in each study.

\section{Review of literature}

Fischer et al. (1984) found that propionic acid rises prior to the failure of digesters for treating swine waste. Nakakubo (2008) concluded that butyrate, valerate, and isobutyrate could be used as the warning indicators in continuous stirred tank reactors (CSTR) for pig manure treatment, whereas acetate and propionate were not suitable. Li (2014) performed AD of food waste by a CSTR, and concluded that several coupled indicators, such as alkalinity ratios (IA/BA, BA/TA), VFA ratio, and alkalinity (VFA/BA) could be used for reflecting the metabolism of AD system to generate rapid and effective early warnings. Furthermore, Martín-González (2013) recommended an IA/PA ratio $<0.3$ for maintaining stable operation in mesophilic AD process of sorted organic fractions from municipal solid waste.

However, there are few studies evaluating the instability of chicken manure anaerobic digestion. Therefore, early warning indicators applicable to indicate instability during the $\mathrm{CM}$ AD process were determined in this study. Instability mechanisms of high-nitrogen substrate AD were analyzed. Controlled measures were recommended to ensure stable mesophilic $\mathrm{AD}$ of $\mathrm{CM}$.

\section{Materials and methods}

\section{Substrate and inoculum}

Five batches of CM were collected from a chicken farm (Chengdu, China), then, the $\mathrm{CM}$ was stored at $4{ }^{\circ} \mathrm{C}$ after removing visible bristles. $\mathrm{CM}$ characteristics, such as the 
total solid (TS), volatile solid (VS), total carbonate (C \% TS), total nitrogen (N \% TS), and the ratio of $\mathrm{C}$ and $\mathrm{N}(\mathrm{C} / \mathrm{N})$ were analyzed and listed in Table 1.

Table 1. Composition of chicken manure

\begin{tabular}{c|c|c|c|c|c}
\hline Characteristics & Batch 1 & Batch 2 & Batch 3 & Batch 4 & Batch 5 \\
\hline TS $(\mathrm{g} / \mathrm{kg})$ & 207.1 & 174.4 & 155.8 & 215.3 & 262.3 \\
VS (g/kg) & 119.0 & 122.0 & 119.0 & 125.0 & 146.0 \\
Carbon (\%TS) & 29.6 & 29.8 & 30.1 & 30.5 & 29.0 \\
Nitrogen (\%TS) & 3.1 & 3.2 & 3.2 & 3.3 & 2.3 \\
C/N & 9.5 & 9.4 & 9.4 & 9.3 & 12.9 \\
Ammonia nitrogen (mg/L) & 2800 & 3000 & 2820 & 2900 & 2750 \\
\hline
\end{tabular}

The inoculum was the digested residue taken from an $\mathrm{AD}$ for pig waste treatment. The inoculum was acclimated for $25 \mathrm{~d}$ in the CSTR system under mesophilic conditions $\left(35^{\circ} \mathrm{C}\right)$ fed $\mathrm{CM}$ as a substrate until the methane contents were $>60 \%$. The $\mathrm{pH}$ in the acclimated inoculum was 7.5.

\section{$A D$}

A bench-scale CSTR with a working volume of $55 \mathrm{~L}$ was operated at mesophilic conditions $\left(35 \pm 2{ }^{\circ} \mathrm{C}\right)$ as shown in Figure 1. The reactor was designed by laboratory, which was heated by the electric heating layer and mixed with a motor. An gas flowmeter and online biogas analyzer were used to measure the biogas produciton and contents of methane $\left(\mathrm{CH}_{4}\right)$ and carbon dioxide $\left(\mathrm{CO}_{2}\right)$, respectively. Other indicators, such as temperature, $\mathrm{pH}$, and redox potential, were monitored using the online liquid monitoring system. The substrate tank was stirred 8 times per day at $40 \mathrm{rpm}$ for $30 \mathrm{~min}$ to maintain the material in a constant state.

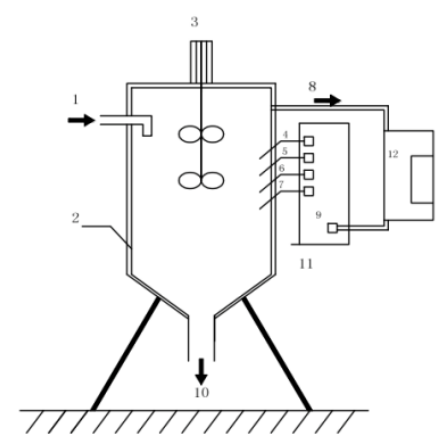

Figure 1. Schematic diagram of the CM AD in CSTR. (1. Feed inlet, 2. Heating layer, 3. Rabbler, 4. $p H$ probe, 5. Oxidation reduction probe, 6. Electrical conductivity probe, 7. Temperature probe, 8. Air outlet, 9. Gas flow indicator, 10. Discharge outlet, 11. Instrument cabinet, 12. Automatic monitoring instrument for methane analysis)

The mesophilic AD of CM was carried out at OLRs of 1.0, 2.0, 3.0, 4.0, 5.0, 6.0, and $7.0 \mathrm{~g} \mathrm{VS} /(\mathrm{L} \cdot \mathrm{d})$. After successful start-up, AD was operated in semi-continuous mode. The substrate was added once per day after sampling. By restricting the total feed to 
$2.75 \mathrm{~kg}$, the hydraulic retention time (HRT) was set at $20 \mathrm{~d}$. The daily feedstock amount and discharge is for different OLRs listed in Table 2.

Table 2. Operating conditions for the mesophilic AD of CM

\begin{tabular}{c|c|c|c|c|c|c}
\hline \multirow{2}{*}{ Period } & Running time & OLR & HRT & \multicolumn{2}{|c|}{ Daily feedstock (g) } & Daily discharge \\
\cline { 5 - 6 } & $(\mathbf{d})$ & $(\mathbf{g ~ V S} /(\mathbf{L} \cdot \mathbf{d}))$ & $(\mathbf{d})$ & $\mathbf{C M}$ & Water & $(\mathbf{g})$ \\
\hline \multirow{2}{*}{ Starting stage } & $1-30$ & 1.0 & 20 & 463 & 2287 & 2750 \\
& $31-60$ & 2.0 & 20 & 926 & 1824 & 2750 \\
\hline \multirow{3}{*}{ Steady stage } & $61-90$ & 3.0 & 20 & 1352 & 1398 & 2750 \\
& $91-120$ & 4.0 & 20 & 1848 & 902 & 2750 \\
& $121-150$ & 5.0 & 20 & 2310 & 439 & 2750 \\
\hline \multirow{2}{*}{ Inhibition stage } & $151-180$ & 6.0 & 20 & 2640 & 110 & 2750 \\
& $181-200$ & 7.0 & 20 & 2636 & 114 & 2750 \\
\hline
\end{tabular}

\section{Analytical methods of samples}

TS and VS were measured by standard methods (Walter et al., 1998). C and $\mathrm{N}$ were monitored by a Vario EL element analyzer (Elementar Analysensysteme GmbH, Germany). Daily gas production and cumulative gas production were analyzed online by the gas flowmeter manufactured by Beijing Sevenstar Electronics Co., Ltd in China. Biogas compositia analyses were performed online by an automatic biogas analyzer made in Wuhan Cubic Optoelectronics Co., Ltd, China. Individual VFA were measured by a gas chromatographer (GC, Agilent-6890N) equipped with a flame ionization detector (FID) (Li et al., 2010). Partial alkalinity (PA), total alkalinity (TA), intermediate alkalinity (IA), and bicarbonate alkalinity (BA) were monitored by a ZDJ4B Automatic Potentiometric Titrator (Shanghai Precision \& Scientific Instrument Co., Ltd, China), in accordance with the methods of Anderson and Yang (1992). The alkalinity was titrated to a PA of pH 5.75, and an IA of pH 5.75 to 4.30 (Ripley et al., 1986). The $\mathrm{pH}$ end-point for TA was 4.00. BA was calculated from Equation 1 (Jenkins et al., 1983).

$$
B A=1.25 P A
$$

where BA is bicarbonate alkalinity $(\mathrm{mg} / \mathrm{L})$ and $\mathrm{PA}$ is partial alkalinity $(\mathrm{mg} / \mathrm{L})$. TAN was determined by Nessler's reagent spectrophotometry according to Chinese Standard (GB 7479-87). The FA was calculated by Equation 2 (Kayhanian, 1999).

$$
F A=\frac{T A N \times K_{a}}{K_{a}+[H]}
$$

where FA is represented by FA concentration $(\mathrm{mg} / \mathrm{L})$, TAN is represented by TAN concentration $(\mathrm{mg} / \mathrm{L}), \mathrm{K}_{\mathrm{a}}$ is represented by temperature dependent dissociation constant $\left(25^{\circ} \mathrm{C}: 0.564 \times 10^{-9}, 35^{\circ} \mathrm{C}: 1.097 \times 10^{-9}, 55^{\circ} \mathrm{C}: 3.77 \times 10^{-9}\right)$, and $[\mathrm{H}]$ is represented by hydrogen ion concentration $\left(10^{-\mathrm{pH}}\right)$. 


\section{Results and discussion}

\section{Volumetric methane production rate (VMPR) and methane yield (MY)}

Methane generation is an important parameter for the stability of AD. VMPR and MY were to describe the biogas production process. The HRT was 20 days and OLR was maintained at a steady-state in the latter 10 days. Figure $2 a$ and $b$ presents the VMPR and MY of seven OLRs 1.0-7.0 $\mathrm{g} \mathrm{VS} /(\mathrm{L} \cdot \mathrm{d})$.

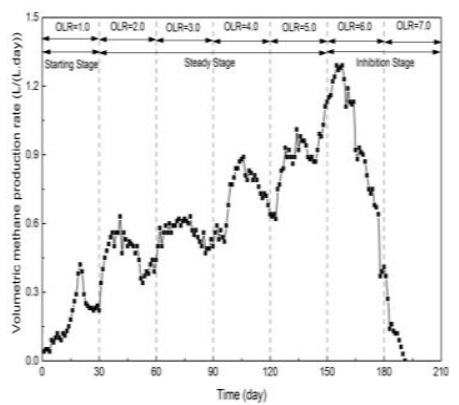

a

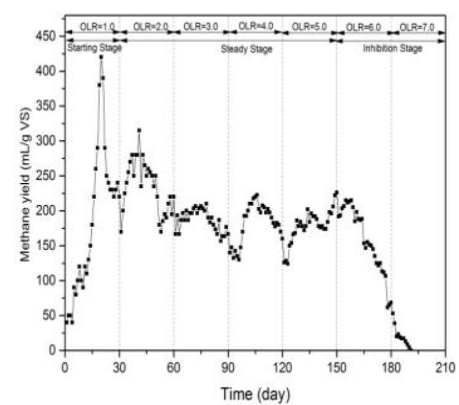

b

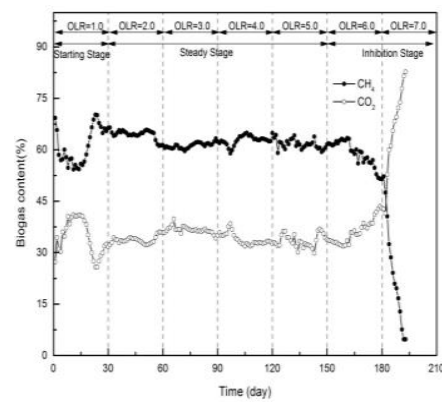

C

Figure 2. Evaluation of (a) volumetric biogas production rate, (b) material yield, and (c) biogas content

During the starting stage, VMPR was low $(0.22-0.39 \mathrm{~L} / \mathrm{L} \cdot \mathrm{d}))$. Subsequently, AD reached a steady stage, where VMPR increased continually with the increase in OLR. The VMPR was achieved at $0.44,0.57,0.81$, and $1.13 \mathrm{~L} /(\mathrm{L} \cdot \mathrm{d})$ at OLR of $2.0,3.0,4.0$, and $5.0 \mathrm{~g} \mathrm{VS} /(\mathrm{L} \cdot \mathrm{d})$, respectively. As $\mathrm{AD}$ reached the inhibition stage (6.0$7.0 \mathrm{~g} \mathrm{VS} /(\mathrm{L} \cdot \mathrm{d}))$, VMPR began to decline until methane production ceased on day 191.

MY reflects the biotransformation of substrate by AD microorganisms, which illustrates the metabolic process of microorganisms. In the starting stage, MY was in the range of 220-390 mL/g VS. With OLR increase, the MY of AD displayed a narrower range between 155 and $225 \mathrm{~mL} / \mathrm{g}$ VS. During the inhibition stage, MY decreased sharply to zero.

\section{Biogas contents}

$\mathrm{CH}_{4}$ is the terminal metabolite of anaerobic digestion, and it can directly reflect the metabolic activity of methanogens (Charles et al., 2011). As shown in Figure 2c, in the initial 20 days of the starting stage, $\mathrm{CH}_{4}$ content was less than $60 \%$ and $\mathrm{CO}_{2}$ content was approximately $40 \%$. During the steady stage, the $\mathrm{CH}_{4}$ and $\mathrm{CO}_{2}$ contents were maintained at $60 \%-65 \%$ and $30 \%-35 \%$, respectively. As OLR increases to 6.0 $7.0 \mathrm{~g} \mathrm{VS} /(\mathrm{L} \cdot \mathrm{d})$, the $\mathrm{CH}_{4}$ contents decrease to $<60 \%$ on the 165 th day. Then, $\mathrm{CH}_{4}$ contents drop rapidly to $<50 \%$ on 180 th day, while $\mathrm{CO}_{2}$ contents increase.

\section{VFAs}

VFAs are the important intermediate metabolite of $\mathrm{AD}$, which are mainly generated from hydrolysis and acidogenesis. All VFAs must first be degraded to acetate then degraded to methane. The conversion rate of different individual VFAs varies in the following order: acetate $>$ n-butyrate $>$ propionic acid (Ren et al., 2003). Propionic acid value was suggested as early warning indicators for the $\mathrm{AD}$ failure of pig manure 
treatment (Pullammanappallil et al., 2011). Hill (1988) showed that iso-acid value would be a better indicator, while Ahring (1991) recommended that the concentration of butyrate acid and its isoforms could be indicated early AD instability.

In this study, individual VFAs, including acetate, propionate, $n$-butyrate, isobutyrate, $n$-Valerate, and iso-Valerate, were detected each day, as shown in Figure 3. It was clear that each individual VFA increased with OLR, especially during the inhibition stage. Individual VFAs fluctuated slightly as the OLR to $1.0 \mathrm{~g} \mathrm{VS} /(\mathrm{L} \cdot \mathrm{d})$, owing to the microorganism community adapting to the new material. During the steady stage, VFA levels maintained a stable range. As the OLR lower than $4.0 \mathrm{~g} \mathrm{VS} /(\mathrm{L} \cdot \mathrm{d})$, acetate and propionate concentration remained below 1000 and $100 \mathrm{mg} / \mathrm{L}$, respectively. Values of $n$-butyrate, iso-butyrate, $n$-Valerate, and iso-Valerate were bellow 60, 50, 10, and $80 \mathrm{mg} / \mathrm{L}$, respectively. With the OLR increase from 4.0 to $5.0 \mathrm{~g} \mathrm{VS} /(\mathrm{L} \cdot \mathrm{d})$, the concentration of acetate and propionate reached more than 1500 and $250 \mathrm{mg} / \mathrm{L}$, respectively.

As OLR higher than $5.0 \mathrm{~g} \mathrm{VS} /(\mathrm{L} \cdot \mathrm{d})$, individual VFAs increased dramatically. Among these, acetate and propionate increased by more than 4 and 9 times during the inhibition stage to $14387 \mathrm{mg} / \mathrm{L}$ and $2818 \mathrm{mg} / \mathrm{L}$, respectively. The other VFAs, such as $n$-butyrate, iso-butyrate, $n$-Valerate, and iso-Valerate, increased by approximately 40 , 26, 32, and 19 times during the instability period, respectively. This could lead to the irreversible acidification of AD, adversely affecting the methanogenesis process and even terminating gas production. The detailed VFA changes are listed in Table 3.

Table 3. Significant changes in indicator level during inhibition stage

\begin{tabular}{c|c|c|c|c}
\hline Indicators & Sudden change & $\begin{array}{c}\text { Days of sudden } \\
\text { change (d) }\end{array}$ & $\begin{array}{c}\text { Threshold of } \\
\text { inhibition }\end{array}$ & Warning time (d) \\
\hline $\mathrm{CH}_{4}(\%)$ & $56 \rightarrow 54$ & 175 & $<55$ & 16 \\
$\mathrm{CO}_{2}(\%)$ & $38 \rightarrow 41$ & 175 & $>40$ & 16 \\
$\mathrm{pH}$ & $\mathrm{No}$ & $/$ & $/$ & $/$ \\
$\mathrm{ORP}(\mathrm{mV})$ & $-535 \rightarrow-524$ & 169 & $>-530$ & 22 \\
Acetate (mg/L) & $1600 \rightarrow 2044$ & 167 & $>2000$ & 24 \\
Propionate (mg/L) & $320 \rightarrow 441$ & 169 & $>400$ & 22 \\
$n$-Butyrate (mg/L) & $45 \rightarrow 75$ & 167 & $>50$ & 24 \\
$i$-Butyrate (mg/L) & $51 \rightarrow 99$ & 167 & $>50$ & 24 \\
$n$-Valerate (mg/L) & $8 \rightarrow 18$ & 167 & $>10$ & 24 \\
$i$-Valerate (mg/L) & $88 \rightarrow 126$ & 168 & $>100$ & 23 \\
$\mathrm{TA}(\mathrm{mg} / \mathrm{L})$ & $\mathrm{No}$ & $/$ & $/$ & $/$ \\
$\mathrm{BA}(\mathrm{mg} / \mathrm{L})$ & $\mathrm{No}$ & $/$ & $/$ & $/$ \\
$\mathrm{IA}(\mathrm{mg} / \mathrm{L})$ & $2926 \rightarrow 3284$ & 174 & $>3000$ & 24 \\
$\mathrm{TAN}(\mathrm{mg} / \mathrm{L})$ & $\mathrm{No}$ & $/$ & $/$ & $/$ \\
$\mathrm{FA}(\mathrm{mg} / \mathrm{L})$ & No & $/$ & $>0.2$ & 24 \\
$\mathrm{VFA} / \mathrm{TA}$ & $0.19 \rightarrow 0.23$ & 174 & $>0.2$ & 24 \\
$\mathrm{VFA} / \mathrm{BA}$ & $0.17 \rightarrow 0.22$ & 174 & $>0.15$ & 18 \\
$\mathrm{IA} / \mathrm{BA}$ & $0.13 \rightarrow 0.15$ & 180 & $<0.80$ & 4 \\
$\mathrm{BA} / \mathrm{TA}$ & $0.81 \rightarrow 0.76$ & 187 & $>12.0$ & 10 \\
$\mathrm{VFA} / \mathrm{FA}$ & $9.6 \rightarrow 12.2$ & 181 & $<1.5$ & 22 \\
$\mathrm{CH} / \mathrm{CO}$ ( & $1.5 \rightarrow 1.1$ & 169 &
\end{tabular}




\section{Total ammonia nitrogen (TAN) and free ammonia $(F A)$}

Ammonia is produced from nitrogenous compounds, which contain protein, phospholipids, nucleic acids, and other nitrogenous lipids (Kayhanian, 1999). Theoretically, all organic nitrogen material in the feedstock can be converted to ammonia $\left(\mathrm{NH}_{3}\right.$ and $\mathrm{NH}_{4}{ }^{+}$). Relationship between the ionized and non-ionized forms of ammonia nitrogen is shown in Equation 3. $\mathrm{NH}_{3}$ is suggested as the main factor of $\mathrm{AD}$ inhibition due to its freely membrane permeable (Kroeker et al., 1979).

$$
\mathrm{NH}_{3}+\mathrm{H}_{2} \mathrm{O} \rightarrow \mathrm{NH}_{4}^{+}+\mathrm{OH}
$$

In this study, the ammonia nitrogen content of substrate was $4000 \mathrm{mg} / \mathrm{L}$. TAN increased slowly from $1040 \mathrm{mg} / \mathrm{L}$ to $3700 \mathrm{mg} / \mathrm{L}$ at day 1 to day 150 (1.0$5.0 \mathrm{~g} \mathrm{VS} /(\mathrm{L} \cdot \mathrm{d}))$ shown in Figure $4 a$. The methane content was over $60 \%$ during these stages. FA increased from 46 to $224 \mathrm{mg} / \mathrm{L}$ with $\mathrm{pH}$ increasing. The level of TAN and FA was low; approximately 3000 and $200 \mathrm{mg} / \mathrm{L}$, respectively, and no inhibition occurred. This contrasts with the conclusion of Velsen (1979), that is TAN concentration above $3000 \mathrm{mg} / \mathrm{L}$ exerts an inhibiting effect on the reactor. With OLR increased to $6.0 \mathrm{~g} \mathrm{VS} /(\mathrm{L} \cdot \mathrm{d})$, TAN and FA increased dramatically. On day 167, TAN concentration was higher than $5000 \mathrm{mg} / \mathrm{L}$, FA exceeded $500 \mathrm{mg} / \mathrm{L}$, and the methane content decreased slightly to $<60 \%$, which was consistent with VFAs increase. Methane contents remained at 55\%-60\%, but volumetric methane generation rate decreased sharply, from 0.91 to $0.43 \mathrm{~L} /(\mathrm{L} \cdot \mathrm{d})$, during days $167-180$. Therefore, the reactor was severely inhibited.

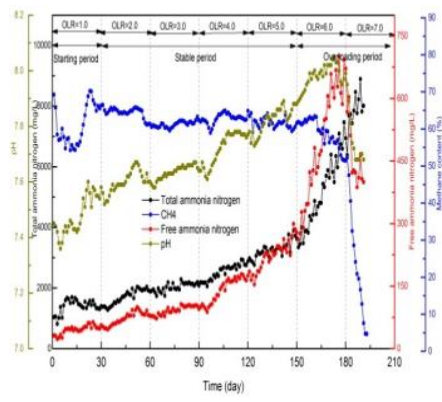

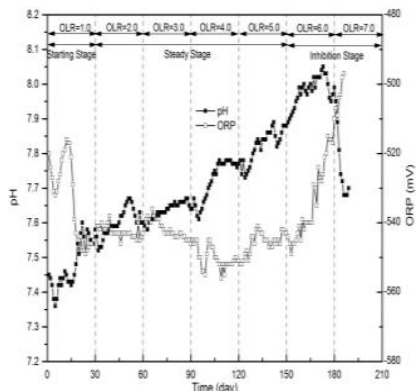

b

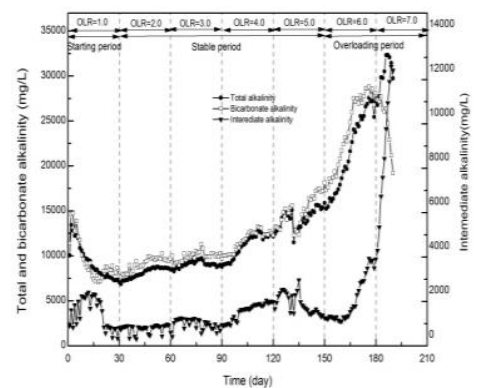

c

Figure 3. Evaluation of (a) total ammonia nitrogen and free ammonia nitrogen, (b) $p H$ and redox potential $(\mathrm{ORP})$, and (c) alkalinity

After 180 days, TAN increased continuously to above $8000 \mathrm{mg} / \mathrm{L}$, $\mathrm{pH}$ decreased from 7.99 to 7.68 , respectively, leading to a slight decrease in FA, with the average value being $456 \mathrm{mg} / \mathrm{L}$. When the VFA levels were higher than $6600 \mathrm{mg} / \mathrm{L}$, volumetric methane production rate decreased $<0.4 \mathrm{~L} /(\mathrm{L} \cdot \mathrm{d})$. When biogas production ceased, TAN, VFA, and FA levels reached $8009 \mathrm{mg} / \mathrm{L}, 20945 \mathrm{mg} / \mathrm{L}$, and $400 \mathrm{mg} / \mathrm{L}$, respectively. TAN increased steadily, with no sudden changes. FA concentration showed a positive correlation to $\mathrm{pH}$ value (correlation coefficient: 0.846). Therefore, TAN and FA values on their own were proved unsuitable for indicating AD instability. It is essential to combine them with other indicators to decide threshold of TAN and FA that inhibits the process of AD. 
$\mathrm{pH}$ is a crucial parameter related to growth and metabolism of microorganism. Accumulation of VFAs could cause $\mathrm{pH}$ to rapidly decrease in the low buffering capacity digester. However, in the high buffering capacity digester (Anderson et al., 1992), especially during fermentation of high ammonia nitrogen material, $\mathrm{pH}$ levels gradually increase until failure. In this study, as shown in Figure $4 \mathrm{~b}, \mathrm{pH}$ value increased from 7.48 to 7.98 during the first 173 days. Although the $\mathrm{pH}$ level declined after day 174, it remained in the normal range, with $\mathrm{pH}$ at an average of 7.74. The $\mathrm{pH}$ value was in the optimal range for fermentation during inhibition stage; however, biogas production and methane content were low. Synergistic action between $\mathrm{NH}_{3}$, VFAs, and $\mathrm{pH}$ lead to a special state called the "inhibited steady state" (Li et al., 2008). Therefore, $\mathrm{pH}$ is not regarded as an early warning indicator in high ammonia nitrogen systems.

\section{Redox potential (ORP)}

The redox potential (ORP) reflects the redox situation in the microbial cell. It is related to the level of $\mathrm{NADH} / \mathrm{NAD}^{+}$, which affects the growth and metabolism of microorganisms (Graef et al., 1999). Some studies suggested a good correlation between the accumulation of VFAs and ORP (Switzenbaum et al., 1990). As shown in Figure $4 b$, ORP fluctuated from $-530 \mathrm{mV}$ to $-510 \mathrm{mV}$ in the first 17 days of the starting stage. Despite the increase of OLR, ORP remained lower than $-530 \mathrm{mV}$ until day 167. The sharp increase in ORP may be due to microorganisms oxidizing NADH to NAD ${ }^{+}$ by producing propionic acid and hydrogen (Eqs. 4-5). Hydrogen was not detected in the gas phase during $\mathrm{AD}$ in this study. That is because hydrogen was consumed by homoacetogenic bacteria or hydrotrophic methanogens (Eqs. 6-7). However, the variation of ORP should be based on the NADH and NAD ${ }^{+}$concentration. In future, it is necessary to quantitatively determine concentrations of $\mathrm{NAD}^{+}$and other related enzymes.

$$
\begin{gathered}
\mathrm{C}_{6} \mathrm{H}_{12} \mathrm{O}_{6}+2 \mathrm{NADH}+2 \mathrm{H}^{+} \rightarrow \mathrm{CH}_{3} \mathrm{CH}_{2} \mathrm{COOH}+2 \mathrm{H}_{2} \mathrm{O}+2 \mathrm{NAD}^{+} \\
\mathrm{NADH}+\mathrm{H}^{+} \rightarrow 2 \mathrm{NAD}^{+}+\mathrm{H}_{2} \\
\mathrm{CO}_{2}+2 \mathrm{H}_{2} \rightarrow \mathrm{CH}_{3} \mathrm{COOH} \\
\mathrm{CO}_{2}+4 \mathrm{H}_{2} \rightarrow \mathrm{CH}_{4}+2 \mathrm{H}_{2} \mathrm{O}
\end{gathered}
$$

\section{Alkalinity}

During $\mathrm{AD}$, buffering capacities are typically evaluated using alkalinity levels, including TA, BA, PA, and IA. Before sudden change of $\mathrm{pH}$, alkalinity is sensitive to accumulation of VFAs. In the anaerobic digester, TA was proved to be insensitive as the result of the combination of VFA and bicarbonate (Björnsson et al., 2001). BA has an empirical correlation with VFA accumulation (Hawkes et al., 1994); thus, BA is used to neutralize VFA instead of TA (Moosbrugger et al., 1993). However, as the ammonia adds alkalinity to the system in the high ammonia system, the relationship is not observed in response to ammonia overload. 
As shown in Figure 4c, alkalinity level showed a constant increasing trend, while the TAN level in the digester increased continuously. During the steady stage, that is 2.0$5.0 \mathrm{~g} \mathrm{VS} /(\mathrm{L} \cdot \mathrm{d}))$, the TA, BA, and IA were at the range of $9000-15000 \mathrm{mg} / \mathrm{L}, 10000$ $17000 \mathrm{mg} / \mathrm{L}$, and $900-2500 \mathrm{mg} / \mathrm{L}$, respectively. For an OLR of $6.0 \mathrm{~g} \mathrm{VS} /(\mathrm{L} \cdot \mathrm{d})$, TA and BA increased obviously from 15000 to $27000 \mathrm{mg} / \mathrm{L}, 17000$ to $28000 \mathrm{mg} / \mathrm{L}$, respectively. IA levels exceeded $3000 \mathrm{mg} / \mathrm{L}$ on day 174 . After 180 days, BA decreased from 28000 to $19000 \mathrm{mg} / \mathrm{L}$ until biogas production ceased, owing to the IA level increasing dramatically to $12576 \mathrm{mg} / \mathrm{L}$, the maximum value. In high ammonia system, the main buffers in $\mathrm{AD}$ are bicarbonate $\left(\mathrm{HCO}_{3}{ }^{-}\right)$and $\mathrm{NH}_{3}$, with a pKa of 6.3 and 9.3, respectively (Moosbrugger et al., 1993) The accumulation of VFA did not lead to a decline in $\mathrm{pH}$ or BA because the ammonia reacts with the accumulated VFA before BA due to the higher pKa. The accumulated VFAs consume BA, producing equivalent IA. Therefore, TA and BA are unsuitable warning indicators due to their insensitivity to the high ammonia system. IA does response to the overloading, so it is thought to be an effective indicator during AD of CM.

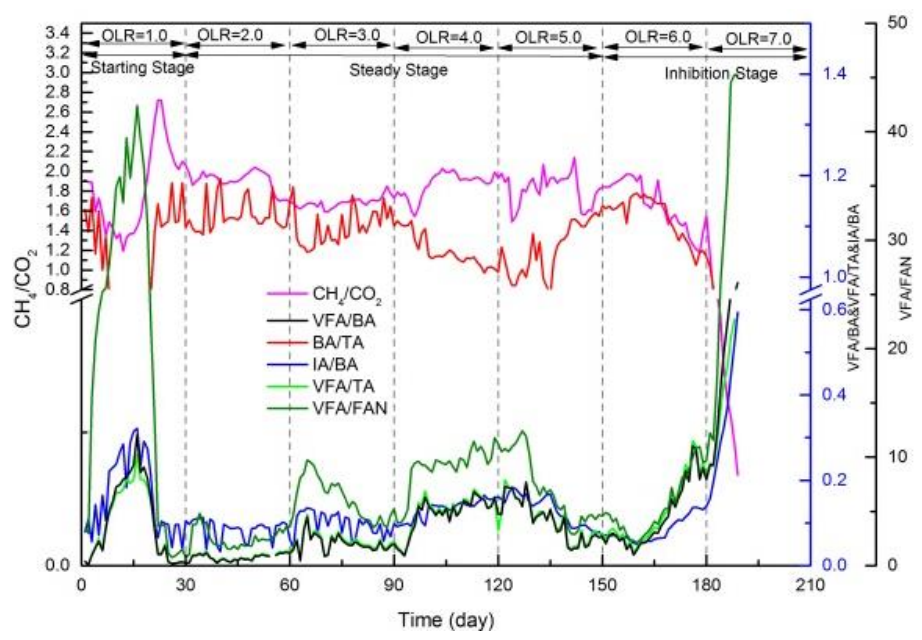

Figure 4. Development of coupling indicators

\section{Screening for early warning indicators}

Gas production rates are potential indicators in the metabolic status of the digester. Lowering gas production rate, compared with influent rate of organic matter, provides a warning of soluble acid product accumulation in the liquid phase. Unfortunately, that is the result of an imbalance rather than a warning of an imbalance. Changes in the biogas production rate depend on HRT, OLR, and feed composition. Moreover, gas production rate is low sensitive to overload compared to other process indicators. Therefore, it is not a significant early warning indicator. Warning time was defined as the day on which the biogas production ceased minus the day of sudden change in this study. Biogas production ceased on day 191.

Several studies defined alkalinity ratio as monitoring parameter to indicate AD instability. Actually, diverse stability limit values have been proposed in many studies dealing with various substrate and experimental conditions (Rincón et al., 2008). In the mesophilic lab-scale upflow anaerobic sludge blanket (UASB) which is reating potatostarch wastewater, the IP/PA ratio of 0.4 was suggested to ensure reactor stable, and 
IA/PA below 0.3 was proposed to maintain operation stable in the AD of municipal solid waste. In this study, combined parameters, including the ratio of $\mathrm{CH}_{4} / \mathrm{CO}_{2}$, VFA/TA, VFA/BA, VFA/FAN, IA/BA, and BA/TA were calculated, as shown in Figure 4, and evaluated as potential indicators of AD instability.

During the starting and stable stages, all ratios became relatively stable after 20 days. However, during the inhibition stage, the ratios increased or decreased by varying degrees. The VFA/BA and VFA/TA curves almost overlapped. Before 150 days, the ratios of VFA/TA and VFA/BA were below 0.2. After 174 days, the ratios increased sharply to 0.98 and 0.66 , respectively, until gas production ceased. However, there were no crucial sudden changes in the ratios of IA/BA and BA/TA. Before 182 days, the range of IA/BA was $0.05-0.15$ whereas $\mathrm{BA} / \mathrm{TA}$ was $0.8-1.2$ prior to 187 days. The sharp curve of the VFA/FA ratio was similar to that of VFA/TA and VFA/BA. Before 181 days, the ratio of VFA/FA was below 12. Early warning days and sudden changes in each indicator are listed in Table 3.

According to the early warning times of VFAs indicators, propionate is later than all other individual VFAs, which is including acetate, n-butyrate, i-butyrate, n-valerate, and i-valerate. In theory, individual VFAs are the most sensitive early warning indicators. Meanwhile, among the combined indicators, the early warning order was $\mathrm{VFA} / \mathrm{BA}=\mathrm{VFA} / \mathrm{TA}>\mathrm{CH}_{4} / \mathrm{CO}_{2}>\mathrm{IA} / \mathrm{BA}>\mathrm{VFA} / \mathrm{FA}>\mathrm{BA} / \mathrm{TA} . \quad$ The VFA/TA, VFA/BA, and IA/BA indicators represent acid-base balance in the system., VFA/TA and VFA/BA were dominant indicators for comprehensively reflecting process status in the high ammonia nitrogen system. The warning time of $\mathrm{CH}_{4}$ was the same as $\mathrm{CO}_{2}$; however, the ratio of $\mathrm{CH}_{4} / \mathrm{CO}_{2}$ showed an earlier warning time than individual biogas contents. Therefore, individual VFAs, as well as the combined indicators, including $\mathrm{CH}_{4} / \mathrm{CO}_{2}$ and VFA/BA, can be selected as early warning indicators for AD of CM instability under mesophilic conditions. The thresholds of each indicator are shown in Table 3.

In our experiments, the biogas content was determined online by an automatic biogas analyzer. $\mathrm{CH}_{4} / \mathrm{CO}_{2}$ was more sensitive to $\mathrm{AD}$ instability owing to the superposition effect. Individual VFAs can be detected online by gas chromatography or near-infrared spectroscopy. It is more convenient for indicators to be monitored online to control AD instability. Therefore, the ratio of $\mathrm{CH}_{4} / \mathrm{CO}_{2}$ and individual VFAs can be monitored online in real time, enabling effective warnings of $\mathrm{AD}$ instability during $\mathrm{CM}$ engineering applications.

\section{Inhibitory conduction process}

High ammonia concentration of substrate and increasing OLR led to ammonia nitrogen accumulation in the system., The difference in intracellular $\mathrm{pH}$ caused transformation between $\mathrm{NH}_{4}{ }^{+}$and $\mathrm{NH}_{3}$ due to ammonia molecules diffusing into the cells of methanogens. Accumulated $\mathrm{NH}_{4}{ }^{+}$may inhibit the methane-synthesizing enzyme, $\mathrm{NH}_{3}$ could break the imbalance of protons and result in a potassium deficiency (Kayhanian, 1999). High concentrations of $\mathrm{NH}_{3}$ mainly inhibit the metabolism of methanogens, particularly aceticlastic methanogens, as well as severely affecting the growth rates of hydrogen-utilizing methanogens (Björnsson et al., 2001). $\mathrm{H}_{2}$ and $\mathrm{CO}_{2}$ is used by homoacetogenic bacteria to produce acetate. These factors caused the increase of acetate concentration during the inhibition stage. Subsequently, the accumulation of propionate, n-butyrate, iso-butyrate, n-valerate, and iso-valerate was observed owing to the inhibition of syntrophic VFA-oxidizing bacteria. With ammonia nitrogen 
concentration increasing, the $\mathrm{pH}$ of the system increased continuously. The $\mathrm{NH}_{3}$ reacted with $\mathrm{CO}_{2}$ induced duringad to form bicarbonate. The buffering capacity increases during $\mathrm{AD}$ owing to the reaction. Therefore, $\mathrm{BA}$ and $\mathrm{TA}$ increased during the stable stage. Due to the accumulation of VFA, on day 180, BA was consumed, producing IA, and releasing the gas phase as $\mathrm{CO}_{2}$. Therefore, BA decreased and IA increased. At the same time, $\mathrm{CO}_{2}$ content increased and $\mathrm{CH}_{4}$ content declined sharply. Finally, acetotrophic methanogens and hydrotrophic methanogens were completely inhibited, causing biogas production to cease.

\section{Conclusions}

For $\mathrm{AD}$ of $\mathrm{CM}$ with high ammonia nitrogen concentration, increasing the OLR led to ammonia accumulation, and high $\mathrm{pH}$ values led to the release of free ammonia. This effected the growth and metabolism of methanogens, causing VFA accumulation and termination of biogas production. For the early warning of $\mathrm{AD}$ instability, $\mathrm{CH} / \mathrm{CO}$, VFA/BA ratios, as well as individual VFAs, are regarded as effective indicators. To measure AD stable operation at a high OLR, it is critically to take suitable measures, including dilution, bioaugmentation, and other efficient methods. In this study, the highammonia nitrogen materials were selected for $\mathrm{AD}$, and the instability early warning indicators were obtained, which provides a theoretical basis for the stable operation of high ammonia nitrogen materials under high loading rate. Furthermore, in the future study, it is necessary to research the microbial community structure in order to analyze the mechism of the instability deeply.

Acknowledgements. The authors would like to gratefully acknowledge research grants from Science and Technology Project of Guangdong Province, PR China (No. 2016A010105017) and (No. 2017B040404009), the National Natural Science Foundation of China (21476222), Youth Innovation Promotion Association CAS (2017423), Program of Strategic Resource Service Network CAS (ZSYS009), Chengdu science and technology Huimin project (2016-HM02-00092-SF), the Key Laboratory of Environmental and Applied Microbiology, and Chengdu Institute of Biology CAS (KLCAS-2016-10).

\section{REFERENCES}

[1] Ahring, B. K., Sandberg, M., Angelidaki, I. (1995): Volatile fatty-acids as indicators of process imbalance is anaerobic digesters. - Appl Microbiol Biotechnol. 43(3):559-565.

[2] Anderson, G. K., Yang, G. (1992): Determination of bicarbonate and total volatile acid concentration in anaerobic digesters using a simple titration. - Water Environ Res. 64(1): 53-59.

[3] Angelidaki, I., Ellegaard, L. (2003): Codigestion of manure and organic wastes in centralized biogas plants. - Applied Biochemistry \& Biotechnology 109(1-3): 95-105.

[4] Björnsson, L., Murto, M., Jantsch, T. G., Mattiasson, B. (2001): Evaluation of new methods for the monitoring of alkalinity, dissolved hydrogen and the microbial community in anaerobic digestion. - Water Research 35(12): 2833-2840.

[5] Charles, W., Carnaje, N. P., Cordruwisch, R. (2011): Methane conversion efficiency as a simple control parameter for an anaerobic digester at high loading rates. - Water Science \& Technology 64(2): 534-539.

[6] Cioabla, A. E., Ionel, I., Trif, G. -tordai, Irimescu, A., Vetres, I. (2013): Study on the Quality of Biogas Obtained from Agricultural Residues during Anaerobic Fermentation. - J Environ Prot. Ecol. 14(1): 247-255. 
[7] Fischer, J. R., Iannotti, E. L., Porter, J. H. (1984): Anaerobic digestion of swine manure at various influent solids concentrations. - Agricultural Wastes 11(3): 157-166.

[8] Graef, M. d., Alexeeva, S., Snoep, J., Teixeira, M. (1999): The steady-state internal redox state (NADH/NAD) reflects the external redox state and is correlated with catabolic adaptation in Escherichia coli. - Journal of Bacteriology 181(8): 2351-2357.

[9] Hashimoto, A. G. (1986): Ammonia inhibition of the methanogenesis from cattle waste. Agricultural Wastes 17: 241-261.

[10] Hawkes, F. L., Guwy, A. J., Hawkes, D. L., Rozzi, A. G. (1994): On-line monitoring of anaerobic digestion: Application of a device for continuous measurement of bicarbonate alkalinity. - Water Science \& Technology 30(12): 1-10.

[11] Hendriksen, H. V., Ahring, B. K. (1991): Effects of ammonia on growth and merphology of thermophilic hydrogen-oxidizing methanogenic bacteria. - Fems Microbiology Ecology 85(3): 241-246.

[12] Hill, D. T., Holmberg, R. D. (1988): Long chain volatile fatty acid relationships in anaerobic digestion of swine waste. - Biological Wastes 23(3): 195-214.

[13] Jenkins, S. R., Morgan, J. M., Sawyer, C. L. (1983): Measuring anaerobic sludge digestion and growth by a simple alkalimetric titration. - Water Pollution Control Federation 55(5): 448-453.

[14] Kayhania, M. (1994): Performance of a high-solids anaerobic-digestion process under various ammonia concentrations. - Journal of Chemical Technology and Biotechnology 59(4): 349-352.

[15] Kayhanian, M. (1999): Ammonia inhibition in high-solids biogasification: an overview and practical solutions. - Environmental Technology 20(4): 355-365.

[16] Kroeker, E. J., Schulte, D. D., Sparling, A. B., Lapp, H. M. (1979): Anaerobic treatment process stability. - Water Environment Research 51(4): 718-727.

[17] Krylova, N. I., Khabiboulline, R. E., Naumova, R. P., Nagel, M. A. (1997): The influence of ammonium and methods for removal during the anaerobic treatment of poultry manure. - Journal of Chemical Technology and Biotechnology 70(1): 99-105.

[18] Li, D., Yuan, Z., Zhang, Y., Sun, Y., Kong, X., Li, L. (2008): Anaerobic biochemical methane potential of organic fraction of municipal solid waste. - Acta Scientiae Circumstantiae 28(11): 2284-2290.

[19] Li, D., Yuan, Z., Sun, Y., Ma, L. (2010): Evaluation of pretreatment methods on harvesting hydrogen producing seeds from anaerobic digested organic fraction of municipal solid waste (OFMSW). - International Journal of Hydrogen Energy 35(15): 8234-8240.

[20] Li, L., He, Q., Wei, Y., He, Q., Peng, X. (2014): Early warning indicators for monitoring the process failure of anaerobic digestion system of food waste. - Bioresource Technology 171: 491-494.

[21] Malollari, I., Kotori, P., Hoxha, P., Lici, L., Lajqi, V., Baruti, B., Cani, X. H., Buzo, R. (2016): Anaerobic codigestion of organic substrate for energetic biogas obtaining and review. - J Environ Prot. Ecol. 17(1):323-330.

[22] Moosbrugger, R. E., Wentzel, M. C., Ekama, G. A., Marais, G. V. R. (1993): A 5 pH point titration method for determining the carbonate and SCFA weak acid/bases in anaerobic systems. - Water Research \& Technology.28(2): 237-245.

[23] Nakakubo, R., Møller, H. B., Nielsen, A. M., Matsuda, J. (2008): Ammonia inhibition of methanogenesis and identification of process indicators during anaerobic digestion. Environmental Engineering Science 25(10): 1487-1496.

[24] Pullammanappallil, P. C., Chynoweth, D. P., Lyberatos, G., Svoronos, S. A. (2001): Stable performance of anaerobic digestion in the presence of a high concentration of propionic acid. - Bioresource Technology 78(2): 165-169.

[25] Qiao, W., Yan, X., Ye, J., Sun, Y., Wang, W., Zhang, Z. (2011): Evaluation of biogas production from different biomass wastes with/without hydrothermal pretreatment. Renewable Energy 36(12):3313-3318. 
[26] Ren, N., Liu, M., Wang, A., Ding, J., Li, H. (2003): Organic acids conversion in methanogenic-phase reactor of the two-phase anaerobic process. - Chinese Journal of Environmental Science 24(4): 89.

[27] Rincón, B., Borja, R., González, J. M., Portillo, M. C., Sáiz-Jiménez, C. (2008): Influence of organic loading rate and hydraulic retention time on the performance, stability and microbial communities of one-stage anaerobic digestion of two-phase olive mill solid residue. - Biochemical Engineering Journal 40(2): 253-261.

[28] Ripley, L. E., Boyle, W. C., Converse, J. C. (1986): Improved alkalimetric monitoring for anaerobic digestion of high-strength wastes. - Water Environment Research 58(5): 406411.

[29] Switzenbaum, M. S., Giraldogomez, E., Hickey, R. F. (1990): Monitoring of the anaerobic methane fermentation process. - Enzyme \& Microbial Technology 12(10): 722-730.

[30] Tampio, E., Ervasti, S., Paavola, T., Heaven, S., Banks, C., Rintala, J. (2014): Anaerobic digestion of autoclaved and untreated food waste. - Waste Management 34(2): 370-377.

[31] Walter, W. G. (1998): Standard methods for the examination of water and wastewater. American Public Health Association, Washington, DC.

[32] Zeeman, G., Wiegant, W. M., Koster-Treffers, M. E., Lettinga, G. (1985): The influence of the total ammonia concentration on the thermophilic digestion of cow manure. Agricultural Wastes 14:19-35. 